\title{
PENGEMBANGAN GAME INTERATIF SMARTPHONE BERBASIS ANDROID PADA MATERI TRIGONOMETRI UNTUK SISWA KELAS X
}

\author{
Muhammad Khoirul Huda ${ }^{1}$ \\ ${ }^{1}$ Program Studi Pendidikan Matematika FKIP Universitas Islam Malang \\ Email: ${ }^{1}$ MuhKhoirulHuda999@gmail.com
}

\begin{abstract}
Abstrak
Tujuan pengembangan ini adalah menghasilkan game interaktif smartphone berbasis android pada Materi Trigonometri Kelas X. Pengembangan modul ini menggunakan model pengembangan 4-D yang meliputi 4 tahap yaitu Define, Design, Development, Dessimminate. Produk yang dihasilkan berupa game interaktif smartphone berbasis android yang telah divalidasi. Validator ahli materi menyatakan cukup valid dengan persentase skor $78.5 \%$, ahli media pembelajaran menyatakan valid dengan presentase skor $86 \%$, dan praktisi menyatakan valid dengan persentase skor 83.4\% Sedangkan hasil validasi pengguna (user) menyatakan modul valid dengan persentase skor 83\% Dengan demikian, dapat disimpulkan bahwa game interaktif smartphone berbasis android pada yang dikembangkan sudah valid untuk digunakan dalam pembelajaran.
\end{abstract}

Kata Kunci: pengembangan, media pembelajaran, game interaktif, smartphone, android, trigonometri

\section{PENDAHULUAN}

Menurut UU nomor 20 tahun 2003 tentang sistem pendidikan nasional, menyatakan bahwa: "Pendidikan nasional berfungsi mengembangkan kemampuan dan bentuk watak serta peradaban bangsa yang bermartabat dalam rangka mencerdaskan kehidupan bangsa, bertujuan untuk berkembangnya potensi peserta didik agar mau menjadi manusia yang beriman dan bertakwa kepada Tuhan Yang Maha Esa, berakhlak mulia, sehat, berilmu, cakap, kreatif, mandiri dan menjadi warga negara yang demokratis dan bertanggungjawab".

Undang-Undang ini mengamanatkan pembaharuan yang besar dalam sistem pendidikan saat ini. Salah satu pembaharuan yang dilakukan pemerintah adalah pembaharuan dalam proses pembelajaran yang menekankan pada penguasaan konsep materi secara tuntas untuk bisa melangkah ke materi selanjutnya. Salah satu upaya yang dilakukan pemerintah adalah dengan memperbaharui kurikulum pembelajaran yang semula dikenal dengan kurikulum KTSP kemudian disempurnakan lagi dengan kurikulum 2013.

Dunia pendidikan juga memerlukan inovasi. Untuk mencapai semua itu, diperlukan paradigm baru oleh seorang guru dalam proses pembelajaran, dari yang semula pembelajaran berpusat pada guru menuju pembelajaran yang inovatif dan berpusat pada siswa (Shoimin, 2014:16). Pembelajaran tidak hanya sekedar transfer of knowledge atau menyampaikan pesan kepada siswa akan tetapi merupakan aktivitas professional untuk menciptakan pembelajaran yang kondusif, inspiratif, menantang dan menyenangkan. Oleh sebab itu, pembelajaran dirancang, dikembangkan, dan dikelola secara kreatif, dinamis, dengan menerapkan multi pendekatan untuk menciptakan suasana pembelajaran yang kondusif.Pembelajaran yang baik ditandai dengan adanya serangkaian kegiatan terencana yang melibatkan siswa secara langsung dan komprehensif, baik fisik, mental maupun emosi.Sehingga pembelajaran menjadi suatu yang sangat berarti bagi kehidupan siswa.

Perkembangan teknologi juga menuntut tersedianya media pembelajaran berbasis teknologi. Hal tersebut mendorong munculnya inovasi media pembelajaran yang menarik, 
canggih, dapat dipelajari secara mandiri, praktis, dan mudah diakses secara online kapanpun dan di manapun sesuai dengan kebutuhan. Inovasi-inovasi yang muncul kemudian melahirkan sebuah konsep pembelajaran berupa e-learning (elektronik learning). Selanjutnya gabungan dari teknologi, komunikasi berupa aplikasi Hand Phone atau mobile phone dengan e-learning menciptakan suatu media pembelajaran m-learning (mobile learning). M-learning dapat diakses melalui perangkat mobile phone maupun perangkat lain seperti PDA dan tablet (persenal computer). Keunggulan dari media pembelajaran berbasis m-learning yaitu kemudahan untuk mengakses dengan aktivitas yang tidak terbatas oleh area. Selain itu, peralatan yang digunakan dalam pembelajaran m-learning canggih, ringan, dan praktis yang memungkinkan digunakan user untuk belajar kapanpun dan dimanapun dalam mobilitas sehari-hari. M-learning juga dapat dikemas secara menarik dalam suatu aplikasi mobile yang variatif dan tidak membosankan.

Perangkat mobile yang sekarang berkembang adalah dalam bentuk smartphone (telepon genggam). Selain dapat digunakan untuk melakukan panggilan suara dan mengirim pesan singkat, smartphone sudah difasilitasi dengan beragram aplikasi dan multimedia sehingga merupakan sebuah alat yang multifungsi. Smartphone bukan lagi menjadi barang asing bagi siswa sekolah menengah di Indonesia dan bahkan sudah menjadi kebutuhan yang tidak dapat ditinggalkan. Siswa dapat menggunakan smartphone untuk mengunduh macammacam games. Siswa juga tidak jarang menggunakan smartphone pada saat pembelajaran berlangsung. Smartphone dapat lebih bermanfaat untuk membantu siswa belajar secara mandiri, smartphone yang sedang digemari dan dimiliki oleh banyak siswa adalah android . Selain harganya relatif murah smartphone bersistem memungkinkan pengguna untuk berkreasi sesuai dengan keinginan karena bersifat tulisan open source.

Demi terciptanya sebuah media pembelajaran yang inovatif dan menarik sekalipun memotivasi siswa untuk belajar, perlu adanya penggabungan antara bentuk game dalam suatu aplikasi berbasis m-learning. Aplikasi tersebut kemudian dinamakan game interaktif smarthphone berbasis android dan digunakan sebagai media pembelajaran.

Game berasal dari kata bahasa inggris yang memiliki arti dasar permainan. Permainan adalah sesuatu yang dapat dimainkan dengan aturan tertentu sehinnga ada yang menang dan ada yang kalah, biasanya dalam konteks tidak serius atau dengan tujuan refresing (Sun,2012). Permainan dalam hal ini merujuk pada pengertian "kelincahan intelektual"(intellec playbility). Game juga bisa diartikan sebagai arena keputusan dan aksi pemainya. Sedangkan menurut Waston (2012) game adalah permaianan yang menggunakan media elektronik, merupakan sebuah hiburan berbentuk multimedia yang di buat menarik mungkin agar pemain bisa mendapatkan sesuatu sehingga adanya kepuasan batin.

Smartphone adalah telepon genggam yang mempunyai kemampuan dengan penggunaan dan fungsi yang menyerupai komputer.

Sedangkan menurut Williams dan Sawyer (2011), smartphone adalah telepon selular dengan menggunakan berbagai layanan seperti, memori, layar, mikroprosesor, dan modem bawaan.

Game interaktif smartphone adalah kegiatan atau permainan kreatif yang berkaitan dengan (kreasi,produksi,distribusi permainan/game smartphone dan video) yang bersifat hiburan, ketangkasan maupun edukasi yang interaktif.

Dari beberapa pendapat tentang pengertian game interaktif smartphone berbasis android dapat disimpulkan bahwa game interaktif adalah kegiatan atau permainan kreatif yang menggunakan media elektronik, merupakan sebuah hiburan berbentuk smarthphone yang dibuat semenarik mungkin yang bertujuan untuk menunjang tercapainya tujuan instruksional dalam pengajaran matematika 
Tujuan pengembangan ini adalah Untuk mendeskripsikan pengembangan gameinteraktif smarthphone berbasis android pokok bahasan trigonometri untuk siswa kelas X.Untuk mendeskripsikan pengembangan game interaktif smarthphone berbasis android akan membantu siswa memahami konsep materi dan mengaitkannya dengan permasalahan nyata, karena materi dalam game interaktif smarthphone ini akan disajikan dengan uraian konsep materi dan implementasi dalam permasalahan nyata sehingga proses pembelajaran akan menjadi bermakna bagi siswa.

\section{METODE}

Game interaktif smartphone berbasis android pada materi trigonometri untuk siswa kelas $\mathrm{X}$ ini dikembangkan dengan model pengembangan 4-D yang dikembangkan oleh Thiagarajan, Semmel dan Semmel. Model ini terdiri atas empat tahap utama yaitu: (1) Define(Pendefinisian/KajianAwal),(2)Design(Perancangan),(3)Develop(Pengembangan), dan (4) Disseminate (Penyebaran) (Trianto, 2007:66).

Jenis data dalam pengembangan ini terdiri dari dua macam yaitu data kualitatif yakni yang diperoleh dari komentar, kritik dan saran pada lembar validasi data, serta data kuantitatif yakni skor penilaian yang ditulis pada angket mengenai kualitas kevalidan game interaktif smartphone berbasis android yang dikembangkan. Teknik analisis data disesuaikan dengan jenis data yang ada. Data kuantitatif diperoleh dari perhitungan skor pada angket, sedangkan data kualitatif diperoleh dari kritik dan saran yang langsung dituliskan oleh ahli materi, ahli media, dan praktisi di lembar validasi kritik dan saran yang berupa evaluasi terhadap game interaktif smartphone berbasis android, bagian yang salah, dan saran perbaikan game interaktif smartphone berbasis androidyang diisi oleh validator ahli, praktisi, dan user.

Lokasi yang digunakan dalam pengembangan ini yaitu SMA Widya Dharma Turen Malang dan MA Darul Huda Klepu Malang. Pengembangan ini melibatkan 2 guru dari ke dua sekolah tersebut.Subjek ujicoba user pada pengembangan ini yaitu9 siswa kelas X.

Adapun prosedur pengembangan game interaktif smartphone berbasis android sesuai dengan model 4-D adalah sebagai berikut.

\section{Define}

Tujuan dari tahap ini adalah untuk menetapkan dan mendefinisikan syarat-syarat penyusunan game interaktif smartphone berbasis android. Dalam menentukan dan menetapkan syarat-syarat penyusunan game interaktif smartphone berbasis android diawali dengan analisis tujuan dari batasan materi yang dikembangkan yaitu hanya materi trigonometri. Tahap define terdiri dari beberapa tahap tahapan tersebutdi awali dengan tahap analisis ujung depan adalah proses mengidentifikasi kebutuhan guru dan kebutuhan siswa. Kemudian tahap selanjutnya adalah tahap analisis siswa, analisis siswa bertujuan untuk mengidentifikasi kebutuhan siswa yang akan menempuh pembelajaran dengan menggunakan game interaktif smartphone berbasis android yang dikembangkan. Hasil analisis ini dijadikan masukan pada saat merancang game interaktif smartphone berbasis android yang akan dikembangkan. Tahap selanjutnya adalah analisis materi. Analisis materi bertujuan untuk mengidentifikasi, merinci, dan menyusun secara sistematis bagian-bagian utama yang relevan yang akan dipelajari siswa berdasarkan analisis ujung depan. Materi yang dipilih dalam pengembangan game interaktif smartphone berbasis android adalah trigonometri. Setelah tahap analisis materi kemudian dilanjutkan dengan tahap analisis tugas. Analisis tugas mencakup pemahaman terhadap materi dan tujuan pembelajaran. Analisis tugas merupakan dasar untuk merumuskan indikator pembelajaran yang akan dikembangkan dalam game interaktif smartphone berbasis android materi trigonometri. Pengembang merumuskan 
indikator pembelajaran berdasarkan kompetensi inti dan Kompetensi dasar dalam kurikulum 2013 sesuai dengan materi yang dikembangkan, yaitu materi trigonometri kelas X.

\section{Design}

Pada tahap ini dilakukan dengan menentukan unsur-unsur yang akan dimasukkan dalam media pembelajaran.

a) Merancang dan menyusun flowchart

Flowchart memuat urutan penyajian mulai dari awal hingga akhir. Flowchart ini sangat penting dan bersifat informatif untuk memberikan gambaran semua alur dan proses dari tampilan ke tampilan lain secara lengkap. Untuk memudahkan pembuatan program, terlebih dahulu menentukan fitur-fitur yang akan disajikan dalam program. Bagan secara keseluruhan diilustrasikan pada Gambar 1 berikut.

Pada tahap ini dilakukan dengan menentukan unsur-unsur yang akan dimasukkan dalam media pembelajaran.

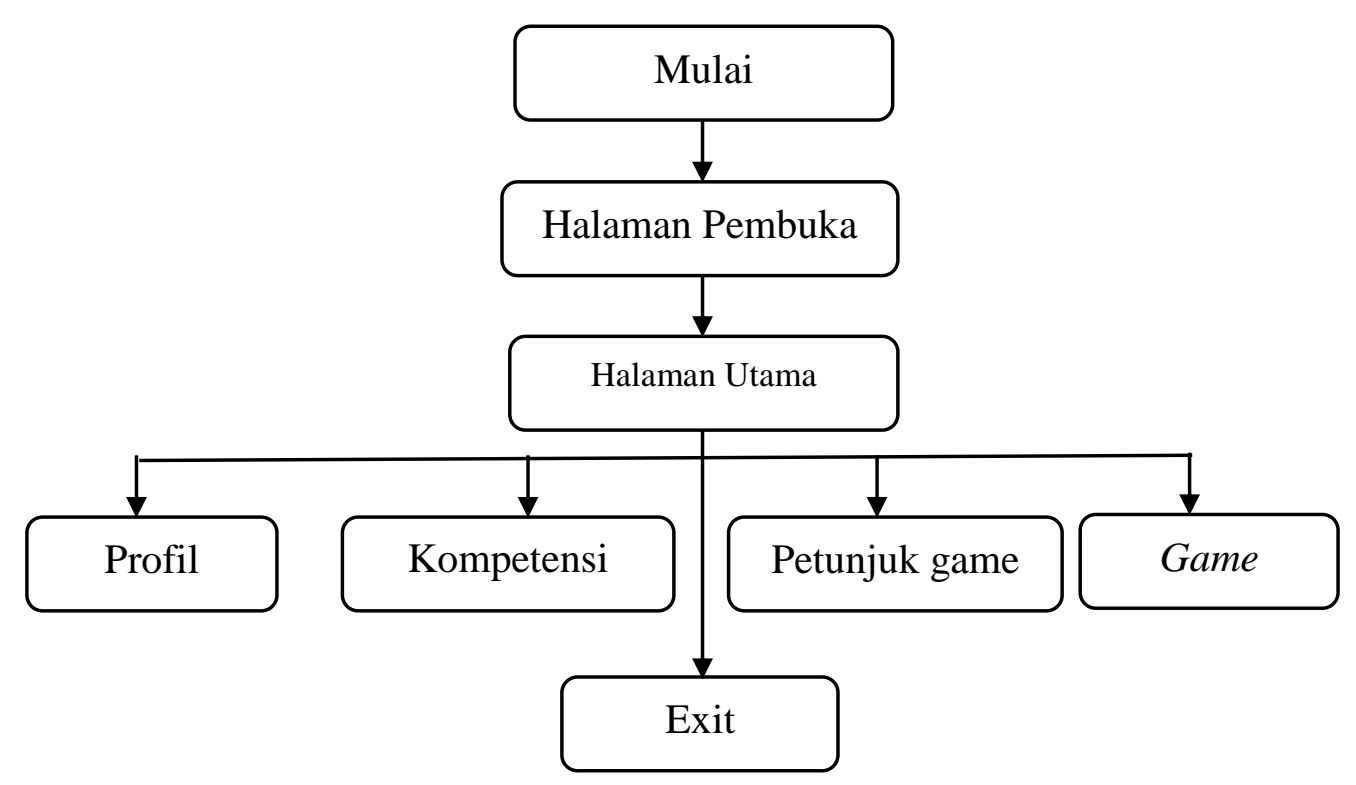

Gambar 1 Bagan Secara Keseluruhan

Ketika program dijalankan, maka program akan menjalankan tampilan pembuka. Tampilan pembuka berisi simulasi singkat mengenai judul game interaktif smarthphone berbasis android dan terdapat proses loading di dalamnya. Ketika loading selesai akan langsung menuju ke halaman utama, maka game interaktif smarthphone berbasis android akan langsung masuk ke halaman utama. Pada halaman utama ini memuat beberapa menu seperti profil, kompetensi, materi,

game dan exit. Ketika pengguna bisa ingin keluar dari program maka langsung saja klik ke menu exit di halaman utama. Penyajian susunan halaman utama game interaktif smarthphone berbasis android disajikan dalam Gambar 3 berikut. 


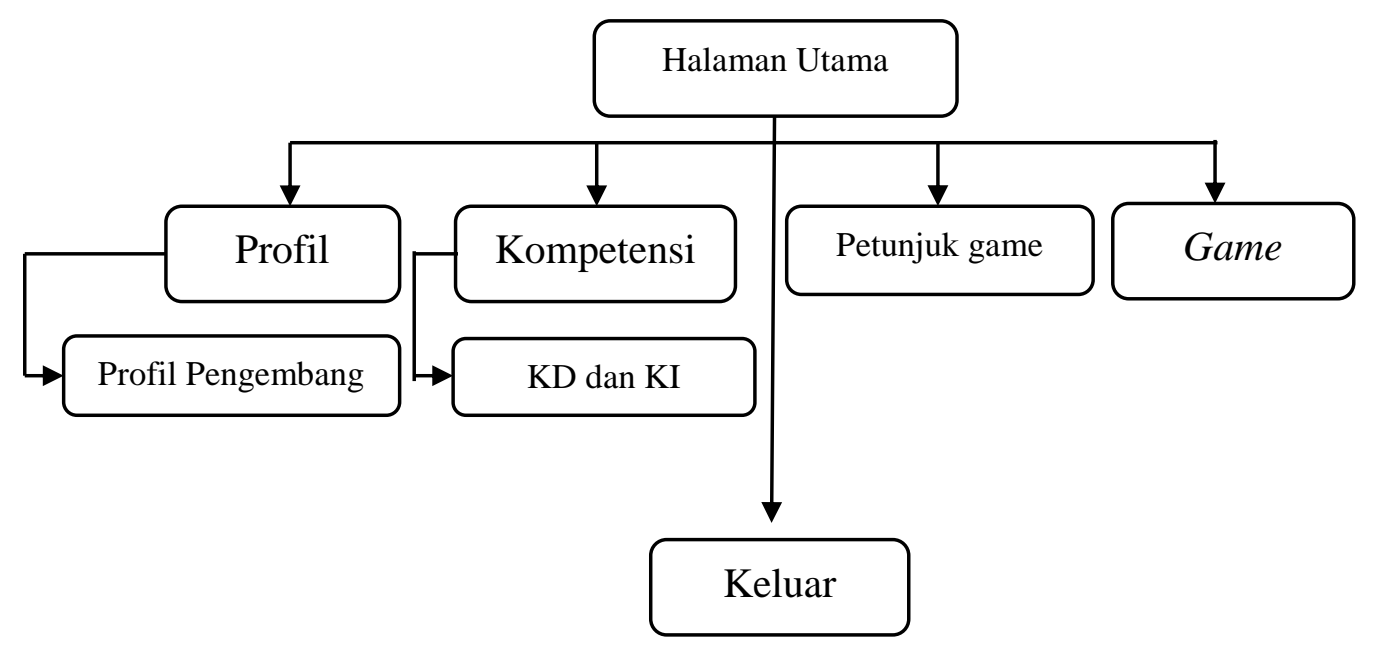

\section{Gambar 3 Susunan Halaman Utama}

b) Mendesain dengan membuat Storyboard

Membuat storyboard adalah proses membuat tampilan pada kertas yang akan dipindahkan pada hand phone. Storyboard ini memuat isi game interaktif yang akan disajikan. Berikut ini dipaparkan storyboard yang terdiri dari: storyboard halaman pembuka dan storyboard halaman utama.

$\checkmark \quad$ storyboard halaman pembuka

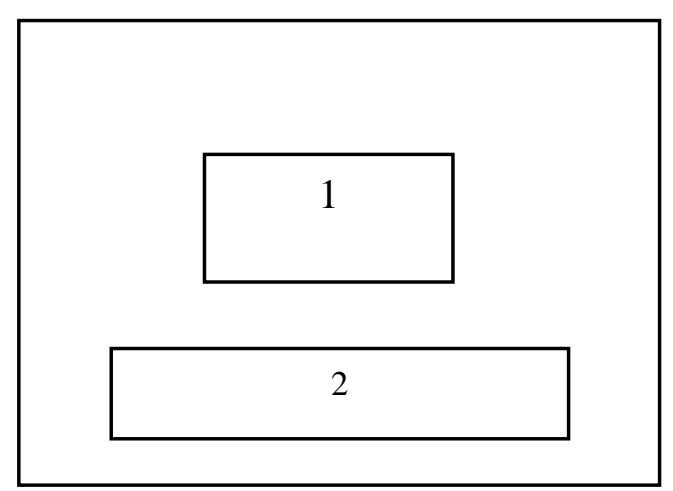

Keterangan gambar :

1. Logo Unisma

2. Loading (proses menuju ke halaman utama)

Gambar 4 Sketsa Tampilan pada Halaman Pembuka

Selesai loading langsung akan menuju ke halaman utama. 


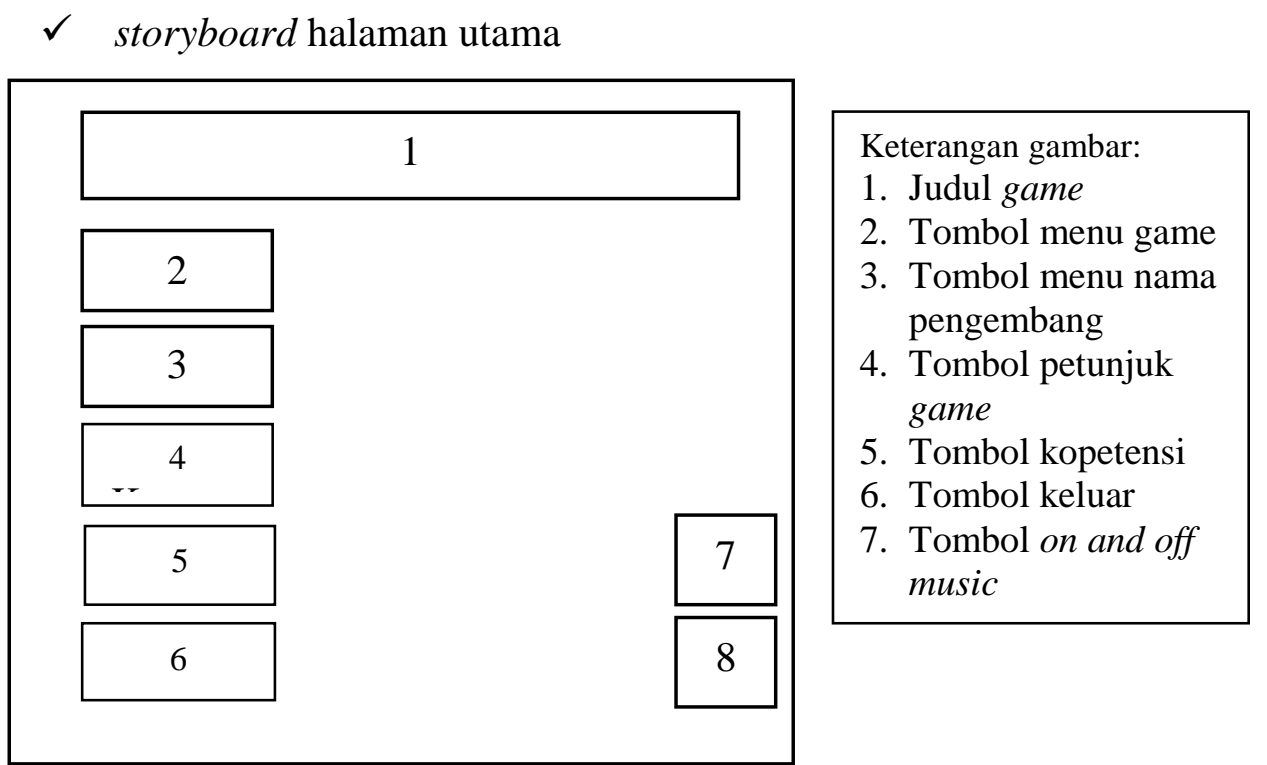

\section{Gambar 5 Sketsa Tampilan pada Halaman Utama}

Untuk mengakhiri program klik tombol exit.

c) Menyusun Instrumen Penelitian berupa angket penilaian game interaktif smarthphone berbasis android.

Pada tahap ini peneliti menyusun instrumen berupa:

a) Lembar validasi instrumen

b) Angket penilaian game interaktif smarthphone berbasis android oleh validator ahli media

c) Angket penilaian game interaktif smarthphone berbasis android ahli materi

d) Angket penilaian game interaktif smarthphone berbasis android oleh praktisi

e) Angket penilaian game interaktif smarthphone berbasis android untuk subjek uji coba

Dari tahap design (perancangan) tersebut, menghasilkan draf 1 game interaktif smarthphone berbasis android yang akan divalidasi oleh validator ahli media, ahli materi dan praktisi. Kemudian draf 1 game interaktif smarthphone berbasis android

\section{Develop} akan dilanjutkan pada tahap develope (pengembangan).

Tujuan pada tahap ini adalah untuk menghasilkan game interaktif smartphone berbasis android materi trigonometri yang sudah direvisi berdasarkan masukan dari para pakar. Pada tahap develop (pengembangan) ini, game interaktif smartphone berbasis android akan dilakukan validasi oleh empat validator, yaitu satu validator ahli materi matematika, satu validator ahli media game interaktif smartphone berbasis android, dan Satu validator praktisi. Setelah empat validator memvalidasi game interaktif smartphone berbasis android, peneliti menganalisis angket penilaian game interaktif smartphone berbasis android yang telah diberikan kepada validator. Jika game interaktif smartphone berbasis android, maka pengembang bisa melakukan uji coba game interaktif smartphone berbasis android kepada kelompok kecil (sembilan siswa). Tetapi jika belum valid, maka pengembang harus melakukan revisi terlebih dahulu, kemudian dikembalikan kepada validator kembali dan jika sudah valid, game interaktif smartphone berbasis android akan disebar kepada kelompok kecil (sembilan siswa) untuk diuji coba.

\section{Develop}

Tahap ini merupakan tahap penggunaan produk (game interaktif smartphone berbasis android) yang telah dikembangkan pada skala yang lebih luas misalnya di kelas lain, di 
sekolah lain, dan oleh guru yang lain. Karena keterbatasan waktu tahap ini tidak dilakukan tahap ini merupakan tahap uji efektifitas produk dengan menggunakan penelitian eksperimen.

\section{HASIL DAN PEMBAHASAN}

Hasil pengembangan ini berupa game interaktif smartphone berbasis android pada materi trigonometri untuk siswa kelas $\mathrm{X}$. game interaktif smartphone berbasis android dirancang menggunakan software Cunstruck 2. Materi dalam game interaktif smartphone berbasis android ini disesuaikan dengan kurikulum 2013.

game interaktif smartphone berbasis android ini membahas materi trigonometri yang terdiri dari mengdeskripsikan hubungan radian ke derajat, mengdeskripsikan hubungan derajat ke radian ;membuktikan sudut-sudut istimewa; menemukan konsep sinus pada suatu segitiga siku-siku; menemukan kosep cosinus pada suatu segitiga siku-siku; menemukan konsep tangen pada suatu segitiga siku-siku; menemukan konsep perbandingan sudut di kuadran II,III, dan IV, terutama untuk sudut-sudut istimewa; menggunakan identitas trigonometri untuk membuktikan identitas trigonometri lainya. Tahap yang dilakukan adalah tahap Define meliputi analisis ujung depan, analisis siswa, analisis materi, dan analisis tugas.Selanjutnya adalah tahap designya itu membuat rancangan game interaktif smartphone berbasis android berupa flowcart dan storyboard, menyusun materi, membuat draft game interaktif berbasis android, membuat instrument penilaian game interaktif smartphone berbasis android. Pada tahap development dilakukan uji validasi draft awal modul kepada validator, yaitu validator ahli, praktisi, dan user. Sedangkan tahap Dessiminate belum terlaksana karena keterbatasan waktu dan biaya.

Berikut bebepara tampilan game interaktif smartphone berbasis android pada materi sistem trigonometri untuk siswa kelas $\mathrm{X}$.

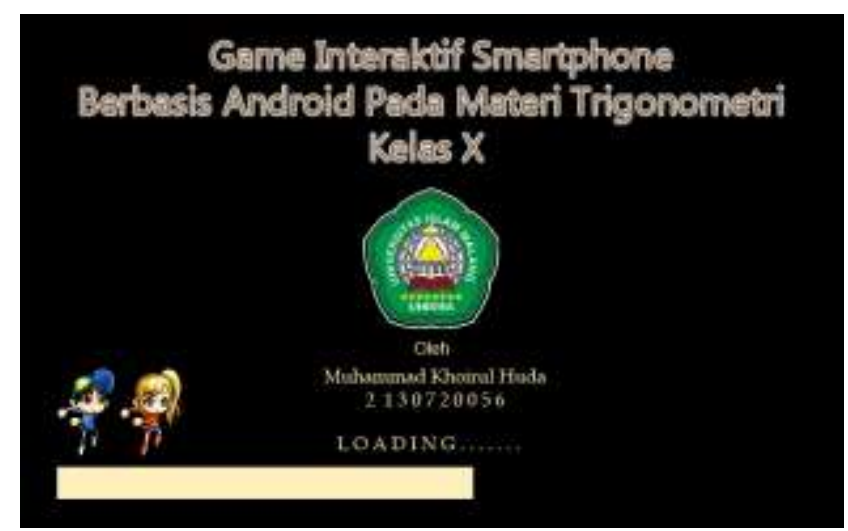

Gambar 6. Intro pembuka game interaktif smartphone berbasis android

Tampilan pembuka berisi simulasi singkat mengenai judul media game interaktif berbasis android dan terdapat proses loading di dalamnya. Selesai loading maka langsung akan menuju ke halaman utama, maka media game interaktif smartphone berbasis android akan langsung masuk ke halaman utama

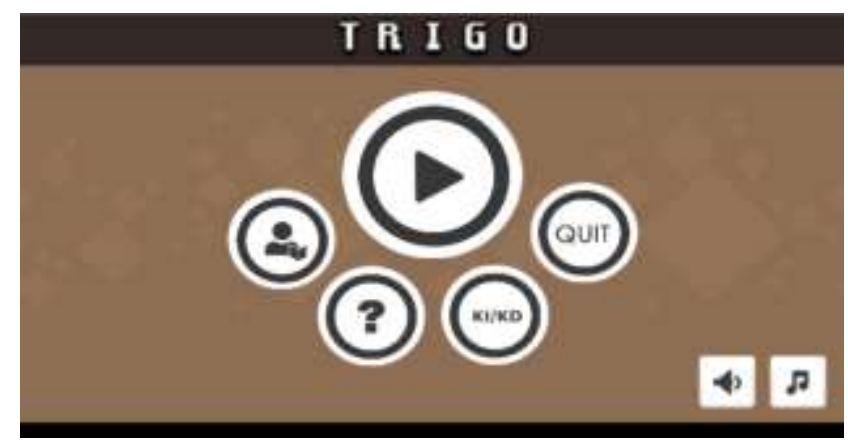


Gambar 7. Halaman utama game interakif smartphone berbasis android Halaman utama game interaktif smartphone berbasis android menampilkan beberapa tombol menu pintasan yang terdiri dari play game, profil pengembang, petunjuk penggunaan, indikator,KI-KD dan quit.

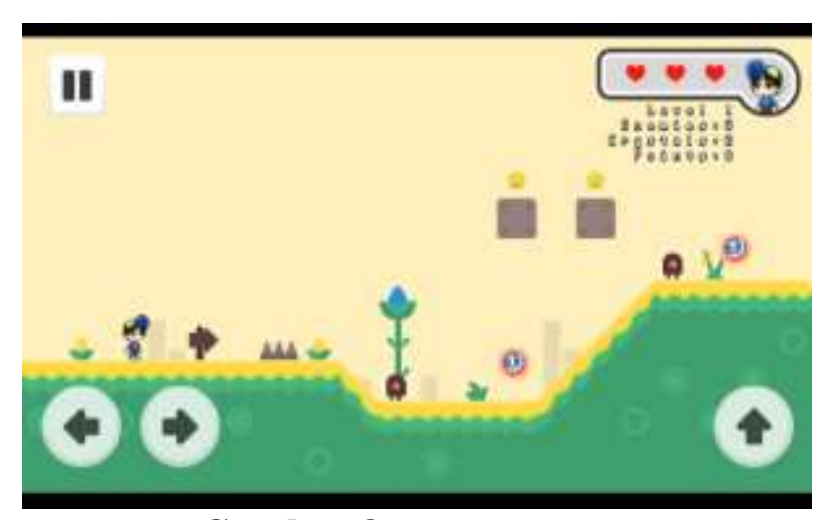

Gambar 8. Tampilan Halaman Game Level 1

Dibagian ini berisikan tampilan materi-materi trigonometri pada game interaktif smartphone berbasis android .Tampilan materi-materi trigonometri dapat dilihat pada Gambar 9 berikut.

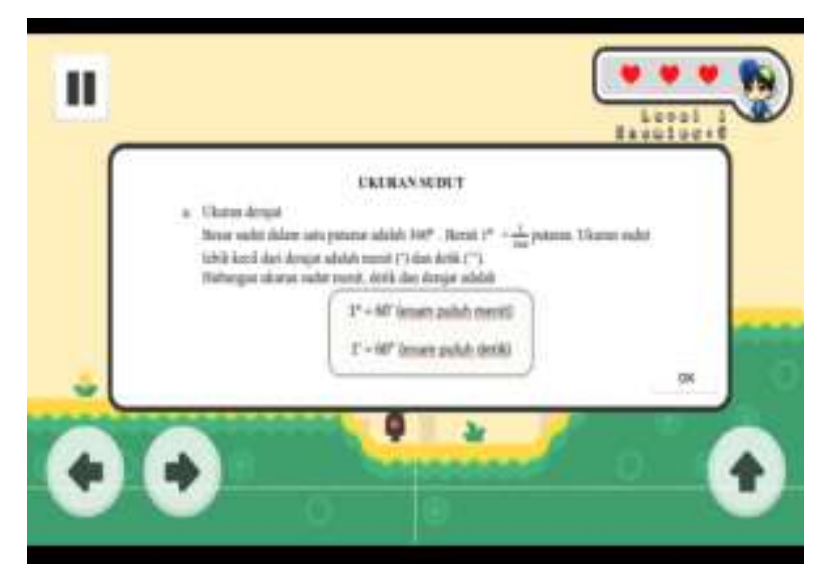

Gambar 9. Tampilan HalamanMateri Game

Dibagian akhir level ini berisikan tampilan quiz. Tampilan quiz dapat dilihat pada Gambar 10 berikut.

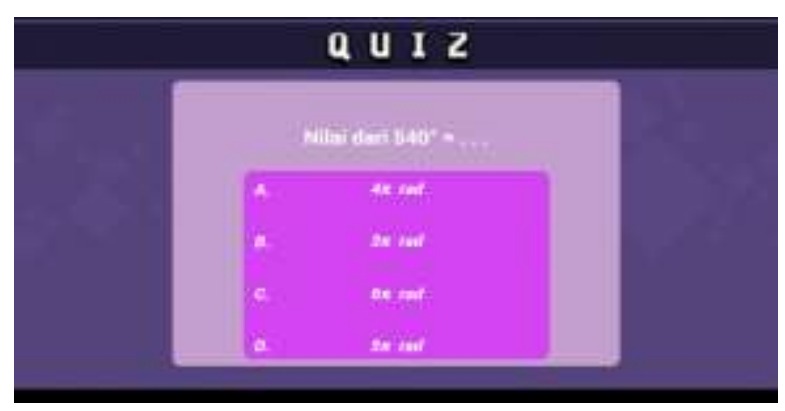

Gambar 10. Tampilan Soal-Soal Quiz

Selanjutnya pada halaman penutup terdiri dari menu quit untuk keluar dari game interaktif berbasis android. Tampilan halaman penutup dapat dilihat pada Gambar 11 


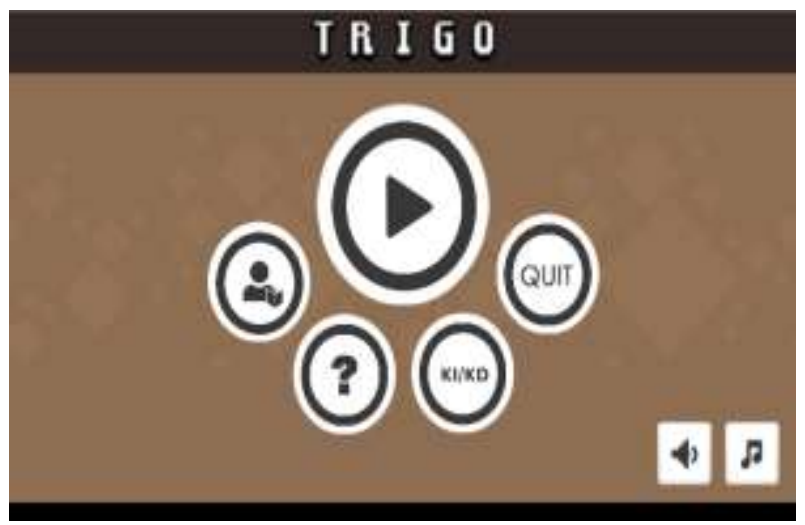

Gambar 11. Tampilan Halaman Penutup

\section{Telaah Ahli}

Pada validasi modul, ada empat validator yaitu tiga validator ahli meliputi ahli materi, ahli media, praktisi, dan user. Berikut adalah hasil validasi ahli, praktisi, dan user.

Berdasarkan data kevalidan produk, ahli materi oleh Sikky El Walida, M.Pd menyatakan $78.5 \%$ produk cukup valid, ahli media oleh Isbadar Nursit, M.Pd menyatakan produk $86 \%$, produ valid, dan praktisi oleh guru matematika MADarul Huda Klepu Malang Iroma Chilfah Dewi, S,Simenyatakan produk 83\%valid, Kemudian hasil validasi dari keetiga validator tersebut dikelompokkan menjadi satu data utuh untuk menyatakan kevalidan game interaktif smartphone berbasis android dan diperoleh nilai rata-rata total dari semua validator adalah $82 \%$ valid. Maka berdasarkan kriteria kevalidan yang telah ditentukan, game interaktif smartphone berbasis android dinyatakan valid.Setelah game interaktif smartphone berbasis android dinyatakan valid, kemudian divalidasikan kepada sembilan siswa kelas X MA Darul Huda semester genap yang terdiri dari tiga siswa berkemampuan matematika baik, tiga siswa berkemampuan matematika sedang dan tiga siswa berkemampuan matematika kurang. Ratarata total penilaian dari semua kelompok pengguna adalah $83 \%$ maka dapat ditarik kesimpulan bahwa untuk game interaktif smartphone berbasis android dinyatakan valid.

\section{SIMPULAN DAN SARAN}

Berdasarkan hasil pengembangan yang menggunakan model pengembangan Four-D menghasilkan produk berupa smartphone sebagai pembelajaran. Dengan game interaktif smartphone berbasis android materi sistem trigonometri, siswa tidak hanya termotivasi untuk mempelajari matematika terutama materi trigonometri. Tetapi siswa dapat menggunakan game interaktif smartphone berbasis android ini sebagai alternatif pilihan belajar untuk menunjang kemampuan matematika.

Cakupan materi yang dikembangkan dalam game interaktif smartphone berbasis android ini masih belum terlalu luas, hanya membahas trigonometri saja, maka disarankan untuk pengembangan selanjutnya supaya memperluas materi atau menambah materi yang lain. Selainitu, dalam tahap validasi user, pengembang hanya menggunakan validasi terbatas dikarenakan terbatasnya waktu.Sehingga,disarankan untuk selanjutnya sebaiknya dilakukan uji coba yang lebih luas dan menguji game interaktif smartphone berbasis android hingga uji keefektifannya.

\section{DAFTAR RUJUKAN}

Arsyad, A. (2011). Media Pembelajaran. Jakarta: PT Rajadrafindo Persada.

Shoimin, A. (2014). 68 Model Pembelajaran Inovatif dalam Kurikulum 2013. Yogyakart a: Ar-Ruzz Media. 
Setyosari, P. (2015). MetodePenelitianPendidikandanPengembangan.Jakarta: Prenada Media Group.

Sun, H. (2012). Apa Itu Game?. http://hafidsun.wodpress.com.

Trianto. (2007). Model Pembelajaran Terpadu dalam Teori dan Praktek. Jakarta: Prestasi Pustaka

Waston. (2012). Game Adalah. https://waston.wordpress.com. 